\title{
"ERNESTO DE TAL" E SUAS DUAS VERSÕES
}

\author{
Flávia Barretto Corrêa Catita \\ Universidade de São Paulo \\ São Paulo, Brasil
}

\begin{abstract}
Resumo: Este artigo tem por objetivo analisar o conto "Ernesto de tal", de Machado de Assis, sob a perspectiva histórica e social. Será objeto de estudo também a comparação entre as duas versões do conto; a primeira, publicada no Jornal das Famílias, e a segunda, publicada no livro Histórias da meia-noite. Por meio da apreciação do cotejo entre as duas versões do conto em questão, procuraremos ainda refletir sobre como Machado criava e reescrevia seus textos.
\end{abstract}

Palavras-chave: Machado de Assis; conto; leitura histórica; crítica genética.

\section{"Ernesto de tal" and its two versions}

\begin{abstract}
This paper aims at analysing Machado de Assis's short story "Ernesto de tal", in the social and historical perspective. The comparison between both versions of the short story will also be studied; the first one published in Jornal das Famílias, and the second one published in the book Histórias da meia-noite. The comparison between the two versions of the short story will help us to think about the way Machado created and rewrote his texts.
\end{abstract}

Keywords: Machado de Assis; short story; historical perspective; genetic criticism.

Partindo do pressuposto de que "qualquer texto repete, imita, plagia ou se inspira em um texto anterior" e de que "a originalidade existe, mas inclui suas origens", acreditamos que os textos da dita primeira fase machadiana são fontes importantes para compreender a gênese dos últimos textos do autor, tão bem acabados, inquietantes e inovadores. Nesse sentido, este trabalho procura se inserir em uma linha de estudos da obra machadiana que tem sua síntese nas palavras de Silviano Santiago:

\footnotetext{
${ }^{1}$ WILLEMART, Philippe. Universo da criação literária: crítica genética, crítica pós-moderna? São Paulo: Edusp, 1993. p. 167.
} 
Já é tempo de se começar a compreender a obra de Machado de Assis como um todo coerentemente organizado, percebendo que à medida que seus textos se sucedem cronologicamente certas estruturas primárias e primeiras se desarticulam e se rearticulam sob forma de estruturas diferentes, mais complexas e mais sofisticadas. ${ }^{2}$

John Gledson, em ensaio sobre "A parasita azul", conto incluído em Histórias da meia-noite, aponta as fortes semelhanças desse conto com outras obras da maturidade de Machado, principalmente Memórias póstumas de Brás Cubas. A respeito das repetições e variações sobre o mesmo tema presentes nas duas obras, ele escreve:

Elas parecem fornecer uma compreensão das operações de sua mente criativa, de como as ideias foram trabalhadas e retrabalhadas, transferidas como um pacote de argumentos, imagens, padrões históricos etc. Elas são evidências, digamos, da tenacidade de sua imaginação, que se agarra a detalhes aparentemente insignificantes tanto quanto a significados mais amplos. É claro, elas são também o melhor testemunho da verdade do "projeto" de Silviano Santiago. ${ }^{3}$

"Ernesto de tal", conto de Machado de Assis publicado primeiramente em março de 1873 no Jornal das Famílias e, posteriormente, no livro Histórias da meianoite, em novembro de 1873, ilustra bem a ideia de amadurecimento da obra e do escritor. Esse conto trata de questões históricas profundas que aparecerão em outros textos de Machado, com o devido ajustamento e refinamento. Mostraremos como muitos dos temas fundamentais da obra "madura" de Machado já aparecem em produções anteriores, como no conto em questão.

"Ernesto de tal" está repleto de referências históricas, descrições de comportamentos e costumes do período que acabam por fornecer uma bela imagem do Brasil do século XIX. A relação entre os homens livres pobres e as condições de

\footnotetext{
${ }^{2}$ SANTIAGO, Silviano. Retórica da verossimilhança. In: Uma literatura nos trópicos: ensaios sobre dependência cultural. 2.ed. Rio de Janeiro: Rocco, 2000. p. 27.

${ }^{3}$ GLEDSON, John. 1872: "A parasita azul" - Ficção, nacionalismo e paródia. In: Cadernos de literatura brasileira, n. 23/24. São Paulo: Instituto Moreira Salles, 2008. p. 174-5.
} 
trabalho que lhes restavam, questão que começava a se configurar na época, também é representada no conto. Como lembra Raymundo Faoro:

A segunda metade do século XIX denuncia o momento do surgimento do trabalhador livre. Ele se emancipa do escravo, substituindo-o e herdando-lhe a função, só pouco a pouco diferenciada na qualidade de assalariado. ${ }^{4}$

Temos então relações de trabalho precárias, sem muitas perspectivas, nada que divirja muito da relação escravo-senhor para os "homens livres", os quais, na verdade eram dependentes dos favores dos mais ricos e poderosos. O tema do favor, definido muito bem por Maria Sylvia de Carvalho Franco como "um forte princípio de dominação pessoal implantada através da troca de serviços e benefícios e que conduzia, no limite, à destruição dos predicados humanos do dependente", 5 tão enraizado na nossa cultura, também aparece em alguns momentos do conto. Entre eles, temos o fato de Rosina morar com o tio, ser uma "agregada"; outro exemplo aparece quando Rosina comenta sobre um suposto bilhete de um primo pedindo dinheiro para o tio. Essas relações que permeiam a nossa história são vistas igualmente no âmbito da carreira profissional. Ernesto (que não tem nem sobrenome) é o funcionário público que ganha pouco, que não tem padrinhos ou influentes conhecidos, nem um futuro profissional muito promissor: "Ernesto porém era difícil que passasse do lugar que tinha no arsenal, e em todo o caso não subiria muito nem depressa. ${ }^{6}$ " Como destacou Roberto Schwarz:

Assim, com mil formas e nomes, o favor atravessou e afetou no conjunto a existência nacional [...]. Esteve presente por toda parte, combinando-se às mais variadas atividades, mais e menos afins dele, como administração, política, indústria, comércio, vida urbana, Corte etc. Mesmo profissões liberais, como a medicina, ou qualificações operárias, como a tipografia, que, na acepção europeia, não deviam

\footnotetext{
${ }^{4}$ FAORO, Raymundo. Machado de Assis: a pirâmide e o trapézio. 4.ed. rev. São Paulo: Globo, 2001. p. 350 .

${ }^{5}$ FRANCO, Maria. Sylvia. de Carvalho. As ideias estão no lugar. In: Cadernos de debate 1 - História do Brasil. São Paulo: Brasiliense, 1976. p. 62.

${ }^{6}$ Todas as citações de trechos do conto tiveram como base a versão original do Jornal das Famílias e a primeira edição do livro Histórias da meia-noite. Em ambos os casos a ortografia foi atualizada, sempre respeitando a pontuação original. As citações foram retiradas de uma edição digital que está sendo elaborada durante o meu projeto de mestrado.
} 
nada a ninguém, entre nós eram governadas por ele. E assim como o profissional dependia do favor para o exercício de sua profissão, o pequeno proprietário depende dele para a segurança de sua propriedade, e o funcionário para o seu posto. O favor é a nossa mediação quase universal. ${ }^{7}$

Como podemos perceber no caso de Ernesto, que não possui muita influência nem amigos importantes, só lhe resta um posto de serviço sem grandes perspectivas. Ele "ocupava um emprego somenos no arsenal de guerra", não tinha nada para oferecer em troca que possibilitasse uma guinada em sua carreira profissional. $\mathrm{O}$ pobre moço não cumpria alguns requisitos básicos para fazer parte de uma determinada "elite"; nem casaca ele tinha!

O moço de nariz comprido (rival de Ernesto), no entanto, está em situação um pouco melhor. Ele sabe conduzir o jogo social, tem superior "elegância na maneira de arquear os braços, de consertar os cabelos, ou simplesmente de oferecer uma xícara de chá", pode manter uma conversa com o subdelegado e tem "um bom lugar numa casa comercial". Não obstante, é ameaçado de ser demitido no momento em que se distrai escrevendo a palavra "amor" durante o horário de trabalho. Sobre o perigo constante de demissão, Faoro escreve:

Os empregados, caixeiros e guarda-livros sofrem outra ameaça, derivada do medo dos patrões, o olho da rua fatídico (H.M.N., Ernesto de Tal). Todos estão, afinal, debaixo das viravoltas da fortuna, sujeitos aos seus cruéis golpes, que levam à fome, à irremediável pobreza. ${ }^{8}$

Há ainda a menção a um convidado ilustre que impede, indiretamente, que Ernesto vá à festa na casa de Rosina. Esse convidado é o subdelegado, "que além disso é comendador" e ocupa um cargo importante no imaginário e na vida política brasileira da época, tanto que, por causa dele, todos deveriam aparecer de casaca (vestimenta que, sabemos, Ernesto não possuía). Segundo Faoro, "um comendador será recebido com as

\footnotetext{
${ }^{7}$ SCHWARZ, Roberto. Ao vencedor as batatas: forma literária e processo social nos inícios do romance brasileiro. 5.ed. São Paulo: Duas Cidades; Editora 34, 2000. p. 16 (grifos do autor).

${ }^{8}$ FAORO, Raymundo. Machado de Assis: a pirâmide e o trapézio, cit., p. 313 (grifos do autor).
} 
galas que o prestígio da insígnia exige: no mínimo, casaca, traje que nem todos possuem". 9

Outra referência política diz respeito ao visconde de Jequitinhonha (Francisco Jê Acaiaba de Montezuma), árduo defensor da independência e da abolição da escravatura, que aparece citado no trecho abaixo:

Ernesto recolhia o olhar - mais cordato neste ponto que o senador D. Manoel, a quem o visconde de Jequitinhonha dizia um dia no Senado que recolhesse um riso, e continuava a rir -, e tudo acabava em boa e santa paz.

Tal alusão ${ }^{10}$ abrangida no conto mostra como Machado já procurava perscrutar assuntos ligados à política e às atualidades mesmo em obras anteriores à "maturidade". Repare-se também que esse movimento parece acontecer sem maiores pretensões, a informação está lá sem grandes alardes e aparentemente sem propósito, pronta para ser descoberta e examinada por um leitor mais atento.

A referência ao casamento, outra importante instituição social, não passa despercebida em "Ernesto de tal", aliás, podemos encontrar nesse conto um retrato muito interessante das práticas sociais do século XIX. Rosina encara o casamento como uma oportunidade, provavelmente a única, de ascender socialmente. Ela é racional e cuida do seu "sistema" de pretendentes com muito zelo, afinal, o matrimônio para uma mulher em sua condição social naquela época significava muito:

Casar-se representava na vida da mulher uma função importantíssima, pois só com isto ela obtinha um status social mais elevado [...]. Para a mulher - como para o homem - o casamento podia implicar ascensão

\footnotetext{
${ }^{9}$ Idem, p. 47-48.

${ }^{10}$ Depois de muito pesquisar, não pudemos encontrar a referência sobre o acontecimento citado acima. Encontramos, sim, na crônica "O velho Senado", a descrição de semelhante episódio, mas um dos protagonistas não é D. Manoel, e sim Sousa Franco: "De outra vez, Montezuma atacava a Sousa Franco, e este novamente sorria, mas agora a expressão não era alegre, parecia rir de desdém. Montezuma empina o busto, encara-o irritado, e com a voz e o gesto intima-lhe que recolha o riso; e passa a demonstrar as suas críticas, uma por uma, com esta espécie de estribilho: 'Recolha o riso o nobre senador!' Tudo isto aceso e torvo. Sousa Franco quis resistir; mas o riso recolheu-se por si mesmo. (ASSIS, Machado de. O velho Senado. Brasília: Senado Federal / Conselho Editorial, 2004. p. 45 Disponível em: <http://www.senado.gov.br/publicacoes/conselho/asp/pdfS.asp?COD_PUBLICACAO=230>. Acesso em: 13 de agosto de 2012.)
} 
social, mas, para ela, esta era a única maneira de alcançá-la, uma vez que não se lhe permitiam atividades que lhe possibilitassem promover-se socialmente por esforço próprio. ${ }^{11}$

A personagem Rosina é, antes de tudo, a própria figura do pêndulo, da oscilação, da volubilidade e da ideia fixa. O mais importante para ela é casar-se bem, ou pelo menos, casar-se. Em um momento ela despreza Ernesto, em outro procura trazer o rapaz para perto, quando percebe que está ficando sem opções de pretendentes. Rosina representa o movimento duplo brasileiro em que duas coisas antagônicas tentam existir ao mesmo tempo, forçando uma síntese que não se dá:

Em vez de realizar o retorno sobre si, o eu se vê preso na má infinidade de um movimento pendular em que ele bascula interminavelmente entre o mesmo e o outro [...]. É assim, então, que o duplo se forma no Brasil - como o produto inapreensível de uma suspensão de reflexão justamente sobre o limite entre o mesmo e o outro, ou entre as exigências simultâneas de sua distinção e de sua indistinção. ${ }^{12}$

Esse conjunto de formas revela uma experiência histórica e cultural própria de nosso país. O Brasil é, por excelência, o lugar onde capitalismo e escravidão andaram juntos por muito tempo. Dois sistemas aparentemente opostos, impossíveis de serem fundidos, foram a base de nossa história. Se, por um lado, o capitalismo solicitava um sujeito reflexivo, autônomo, dono de si mesmo, que pudesse distinguir sujeito de objeto, por outro lado, a escravidão supunha a coisificação de pessoas, dominação pessoal direta, não autonomia:

Desse modo, situávamos, no Brasil, em face de dois regimes, igualmente bem ancorados na realidade dos fatos e, não obstante, contraditórios e mutuamente exclusivos: um que, exigindo a formação do juízo autônomo, prescrevia a distinção entre o mesmo e o outro; e

\footnotetext{
${ }^{11}$ STEIN, Ingrid. Figuras femininas em Machado de Assis. Rio de Janeiro: Paz e Terra, 1984. p. 32 (grifos da autora).

${ }^{12}$ PASTA JÚNIOR, José Antonio. Singularidade do duplo no Brasil. In: CHEMANA, Roland (Org.). A clínica do especular na obra de Machado de Assis. Paris: Association Lacanienne Internationale, 2005. p. 40 .
} 
um outro regime que tornava inconcebível a distinção entre o mesmo e o outro. ${ }^{13}$

Para reforçar ainda mais a ideia do retrato social brasileiro, o narrador faz questão de explicitar uma data; além do ano de 1850, o mês de outubro é claramente marcado para situar a narração dos acontecimentos. Em uma breve pesquisa, é possível encontrar o decreto de 14 de outubro de 1850, que "Regula a execução da Lei que estabelece medidas para a repressão do tráfico de africanos neste Império". ${ }^{14} \mathrm{Ou}$ seja, este decreto sancionava a Lei Eusébio de Queirós, que proibia o tráfico negreiro no país. Em 1850 também foi aprovada a Lei de Terras, que regulamentava a compra e posse de terras no país.

Lembremos então da frase presente do conto: "Trocadilho de 1850". O que essa frase pode significar no contexto aqui apresentado? Se recordarmos do decreto que proibia o tráfico de escravos no Brasil e pensarmos que essa prática continuou, ainda que clandestinamente, durante vários anos, que a Abolição só viria mais de trinta anos depois, e nos atentarmos ainda para a configuração brasileira que viveu (ainda vive, muitas vezes) uma "ultrapassagem que não supera", ou seja, uma reposição do passado mesmo quando se parece avançar para o futuro, talvez fique clara a sagaz sentença que bem define o nosso país, a qual Machado, com uma despretensão retórica, singelamente inclui em seu texto.

Pelos exemplos citados acima, cremos que o conto "Ernesto de tal", apesar de pertencer à chamada primeira fase machadiana, confirma, em muitos aspectos, a teoria de John Gledson de que "[...] Machado, como muitos outros romancistas do século XIX, desejava retratar a natureza e o desenvolvimento da sociedade em que vivia". ${ }^{15}$ Lendo o conto com um pouco mais de atenção, podemos encontrar descrições sobre fatos

\footnotetext{
${ }^{13}$ Ibidem.

${ }^{14}$ Decreto de 14 de Outubro de 1850. In: COLLECÇÃO DAS LEIS DO IMPERIO DO BRASIL. Tomo XIII. Parte II. Rio de Janeiro: Typographia Nacional, 1851. p. 07. Disponível em: <http://www.camara.gov.br/Internet/InfDoc/conteudo/colecoes/Legislacao/Legimp-37.pdf>. Acesso em: 13 de agosto de 2012.

${ }^{15}$ GLEDSON, John, Machado de Assis: ficção e história. Trad. Sônia Coutinho. 2.ed. rev. São Paulo: Paz e Terra, 2003. p. 25.
} 
históricos, relações de trabalho e costumes sociais da época, todos intermediados pela visão aguda e crítica do nosso maior escritor.

\section{O processo de reescrita em "Ernesto de tal"}

Gostaríamos de expor aqui, de modo breve e ainda em desenvolvimento, algumas mudanças que Machado realizou de uma versão para outra do conto "Ernesto de tal". Lembrando que a primeira versão diz respeito ao texto publicado no Jornal das Famílias $(J F),{ }^{16}$ de março a abril de 1873 , e a segunda versão refere-se à primeira edição do livro Histórias da meia-noite $(H M N),{ }^{17}$ também de 1873 , em que o conto aparece novamente reformulado (ambas as versões foram atualizadas apenas quanto à ortografia).

Logo no início do conto temos a seguinte reformulação, de uma versão para outra:

\begin{tabular}{|c|c|}
\hline$J F$ & $H M N$ \\
\hline $\begin{array}{l}\text { - Com muito gosto, respondeu o outro } \\
\text { ficando pálido como um defunto. Ernesto não } \\
\text { tinha casaca! }\end{array}$ & $\begin{array}{l}\text { - Com muito gosto, respondeu o outro } \\
\text { ficando pálido como um defunto. } \\
\text { Pálido, por quê? Leitor, por mais ridícula e } \\
\text { lastimosa que te pareça esta declaração, não } \\
\text { hesito de dizer-te que o nosso Ernesto não } \\
\text { possuía uma só casaca nova nem velha. }\end{array}$ \\
\hline
\end{tabular}

Em vez de resolver toda a trama e a tensão com uma simples frase, "Ernesto não tinha casaca!", na segunda versão o narrador dialoga com o leitor e explica-lhe com mais detalhes e maior morosidade a situação precária da personagem. Veja-se ainda o procedimento do Machado daquela época, ao trazer os detalhes às claras e deixar o leitor bem informado sobre os acontecimentos da história.

Em outro momento, o elogio ao caráter ordeiro (que também pode ser entendido ironicamente) de Ernesto desaparece na segunda versão:

\begin{tabular}{|c|c|}
\hline$J F$ & $H M N$ \\
\hline Dotado de um grande espírito de ordem e & Fez Ernesto uma lista dos amigos e casacas \\
\hline
\end{tabular}

${ }^{16}$ ASSIS, Machado de. Ernesto de tal. Jornal das famílias - publicação illustrada, recreativa, artistica etc. Rio de Janeiro: Garnier, 1873. Tomo XI. p. 75-88 e p. 97-104.

${ }^{17}$ ASSIS, Machado de. Histórias da meia-noite. Rio de Janeiro: BL Garnier, Livreiro-Editor do Instituto Historico, 1873. 
regularidade, o rapaz fez uma lista dos amigos prováveis [...]

e casacas prováveis [...]

Há também momentos de refinamento da linguagem, como no exemplo abaixo, com o uso do pronome relativo, em "cujos ocupantes", em vez de "todos cheios de homens", e a substituição de "encasacados" por "de casaca", na segunda versão:

\begin{tabular}{|l|l|}
\hline \multicolumn{1}{|c|}{$J F$} & \multicolumn{1}{|c|}{$H M N$} \\
\hline $\begin{array}{l}\text { Imagine-se o desespero de Ernesto; }[. . .] \text { que } \\
\text { ao voltar para casa encontrou três enterros, dois } \\
\text { dos quais com muitos carros, todos cheios de } \\
\text { homens encasacados. }\end{array}$ & $\begin{array}{l}\text { Imagine-se o desespero de Ernesto; [...] que } \\
\text { ao voltar para casa encontrou três enterros, } \\
\text { dous dos quais com muitos carros cujos } \\
\text { ocupantes iam todos de casaca. }\end{array}$ \\
\hline
\end{tabular}

Às vezes, a mudança de um adjetivo pode trazer significados diferentes, como no trecho abaixo:

\begin{tabular}{|c|l|}
\hline \multicolumn{1}{|c|}{$J F$} & \multicolumn{1}{|c|}{$H M N$} \\
\hline Desejos inúteis destes dois rapazes - & $\begin{array}{l}\text { Desejos ambiciosos destes dous rapazes - } \\
\text { inúteis e vãos, porque ela, se alguém lhe } \\
\text { prende a atenção, é um rapaz de bigode louro } \\
\text { e nariz comprido que está agora a conversar } \\
\text { prende a atenção, é um rapaz de bigode louro e } \\
\text { com o subdelegado. }\end{array}$ \\
$\begin{array}{l}\text { nariz comprido que está agora conversando } \\
\text { com o subdelegado. }\end{array}$ \\
\hline
\end{tabular}

A substituição de "desejos inúteis" por "desejos ambiciosos" revela um pouco mais sobre o caráter de Rosina. No primeiro caso, seria impossível para os outros rapazes se aproximarem de Rosina para cortejá-la. No entanto, sabemos que isso não é verdade; desde que o rapaz interessado pudesse oferecer a vida com a qual ela sonhara, nenhum pretendente seria descartado à primeira vista.

$\mathrm{Na}$ segunda versão, o escritor também opta por utilizar o gerúndio, em "conversando", em vez da forma tipicamente lusitana "a + infinitivo". Tal movimento pode resultar em um abrasileiramento do texto, que é trazido para a realidade em que se passa a história.

Outro trecho interessante é o que segue abaixo:

\begin{tabular}{|r|l|}
\hline \multicolumn{1}{|c|}{$J F$} & \multicolumn{1}{|c|}{$H M N$} \\
\hline Rosina conhecia já o novo candidato desde & $\begin{array}{c}\text { Rosina conhecia o novo candidato desde } \\
\text { algumas semanas, mas só naquela noite tivera } \\
\text { ocasião de entreter relações telegráficas com } \\
\text { ele. É difícil dizer quantos telegramas foram } \\
\text { ocemanas; mas só naquela noite tivera } \\
\text { ocasão de o tratar de perto, de consolidar, } \\
\text { drocados durante a noite entre as duas assim, a sua situação. As relações, até } \\
\text { então puramente telegráficas, passaram a ser }\end{array}$ \\
\hline
\end{tabular}


estações; foram tantos que os Estados vizinhos e limítrofes ficaram abalados com receio de perderem uma aliança provável. Alguns chamaram às armas as milícias dos agrados e requebros, dos lenços na boca, dos olhos tenros e das expressões derretidas. Esforço inútil! a aliança dos dois estava assinada. verbais; e se o leitor gosta de um estilo arrebicado e gongórico, dir-lhe-ei que tantos foram os telegramas trocados durante a noite entre eles, que os Estados vizinhos, receosos de perder uma aliança provável chamaram às armas as milícias dos agrados, mandaram sair a armada dos requebros, assestaram a artilharia dos olhos tenros, dos lenços na boca, e das expressões suavíssimas; [...]

Nesse excerto temos uma reestruturação do enredo no sentido de enfatizar algo mais verossímil, já que não seria possível que os namorados trocassem telegramas durante a festa, como consta na primeira versão. As cartas já haviam sido trocadas anteriormente, na segunda versão, e agora os namorados têm a chance de se conhecer com maior proximidade.

É interessante notar também como Machado enfeita, ironiza e parafraseia o discurso romântico da época ao descrever os movimentos de fazer a corte, os galanteios dos namorados etc. Ele também destaca a preferência dos seus leitores por um estilo que parece não ser o dele; um estilo "arrebicado e gongórico", bem característico e afinado com o tipo de leitor da época, o leitor de folhetim, acostumado às histórias românticas e piegas.

Há momentos em que a mudança de uma palavra apenas já modifica todo o sentido do texto:

\begin{tabular}{|c|c|}
\hline$J F$ & $H M N$ \\
\hline $\begin{array}{l}\text { - Tudo está sanado, [...]; ela explicou tudo; } \\
\text { eu tinha visto mal. } \\
\text { - Ah! disse Jorge olhando piedosamente } \\
\text { para o amigo então que diz ela? }\end{array}$ & $\begin{array}{l}\text { - Tudo está sanado, [...]; ela explicou } \\
\text { tudo; eu tinha visto mal. } \\
\text { - Ah! disse Jorge olhando com lástima } \\
\text { para o amigo; então que diz ela? }\end{array}$ \\
\hline
\end{tabular}

Ao trocar o advérbio "piedosamente" pela locução adverbial "com lástima", fica ainda mais clara no texto de Histórias da meia-noite a opinião de Jorge sobre o relacionamento do amigo com Rosina. Na segunda versão, Ernesto é digno de lástima, quem sabe até de desprezo, diferentemente do texto no Jornal das Famílias, em que se pode notar uma certa empatia por parte de Jorge, que parece compartilhar da dor do amigo iludido. 
Muitos dos movimentos de uma versão para outra são de supressão, como no caso abaixo:

\begin{tabular}{|c|l|}
\hline \multicolumn{1}{|c|}{$J F$} & \multicolumn{1}{|c|}{$H M N$} \\
\hline \multicolumn{1}{|c|}{ Dias depois, era um domingo, [...], foram os } & Dias depois, era um domingo, [...] \\
dous namorados interrompidos pelo pequeno que & foram os dous namorados interrompidos \\
descera da cadeira a que trepara, gritando: & pelo pequeno que descera, gritando: \\
- Aí vem ele! aí vem o namorado! & - Aí vem ele! aí vem ele! \\
\hline
\end{tabular}

Ao retirar o trecho "revelador" (entre aspas, porque sabemos que Rosina nunca pôde esconder completamente o seu esquema de pretendentes) em que o menino grita "aí vem o namorado!", tem lugar uma pretensa ocultação das verdades da história, já que não fica tão óbvio que Ernesto sabia de tudo. Dizemos "uma pretensa ocultação" porque não é necessário ser muito sagaz para perceber o que o pobre Ernesto não queria ver.

Durante a reescrita, há longos trechos que foram suprimidos e substituídos por outros mais elaborados:

\begin{tabular}{|c|c|}
\hline 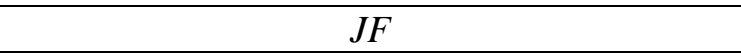 & \\
\hline $\begin{array}{l}\text { Também coube a Ernesto o ensejo de } \\
\text { insinuar alguma cousa a respeito do rival. } \\
\text { - Nova desconfiança? disse } \\
\text { impetuosamente Rosina. } \\
\text { - Não, acudiu Ernesto; desta vez não é } \\
\text { desconfiança. A princípio confesso que } \\
\text { desconfiei; nem era para menos; o dito do } \\
\text { Juquinha (era o nome do filho de Vieira) era } \\
\text { de pôr a pulga atrás da orelha a quem já tinha } \\
\text { tido algumas dúvidas... Mas quando eu vi a } \\
\text { maneira como você o tratou, fiquei tranquilo. } \\
\text { [...] } \\
\text { - Ah! se você fosse a castigar quantos } \\
\text { gostam de mim! } \\
\text { Ernesto ficou roxo. } \\
\text { - O essencial, continuou a moça, é que eu } \\
\text { não lhes preste atenção; e isso... } \\
\text { Ernesto reconheceu a evidência desta } \\
\text { argumentação, pediu desculpa a Rosina e } \\
\text { prometeu rir-se do rival. } \\
\text { Notou entretanto daí a dias que as cartas da }\end{array}$ & $\begin{array}{l}\text { Logo depois desta perspec } \\
\text { felicidade, a concha em que pes } \\
\text { esperanças de Ernesto começou a } \\
\text { pouco. Ele via que Rosina efet } \\
\text { parecia ir diminuindo as cartas [...] } \\
\text { Infelizmente a tática deste namo } \\
\text { perguntar à própria moça se eram fur } \\
\text { suspeitas dele, ao que ela respondia v } \\
\text { que não, e isto bastava a restituir-lhe } \\
\text { espírito.[...] Entretanto, era difícil } \\
\text { verdade não se lhe metesse pelos olho } \\
\text { Desisto de pintar os desesp } \\
\text { terrores, as imprecações de Ernesto } n \\
\text { que a certeza da derrota mais funda }\end{array}$ \\
\hline
\end{tabular}


morava fazendo a si mesmo uma enfiada de perguntas que pareciam não acabar nunca mais.

Ama a outro?

Esfria comigo?

Que será o outro?

Será ele?

[...]

Não conseguiu adotar nenhuma destas resoluções, nem acertou qual das perguntas exprimia a realidade da situação. natureza achar uma resolução qualquer.

Esse trecho do Jornal das Famílias dialoga com o trecho anterior, no qual Juquinha anuncia a chegada do namorado de Rosina. Esse seria um dos motivos para que Ernesto voltasse a desconfiar da moça. Essa suspeita é logo abrandada pelas palavras de Rosina e pela ingenuidade de Ernesto. No entanto, no longo monólogo fatídico do moço fica realçado o melodrama folhetinesco e a incapacidade de Ernesto em tomar resoluções ou enxergar a realidade.

$\mathrm{Na}$ segunda versão, há um desenvolvimento psicológico um pouco mais profundo da personagem e a verdade começa a perturbar-lhe o espírito. Na versão em livro, o trecho é mais elaborado e revela pinceladas engenhosas de ironia e humorismo machadianos. Fica evidente, ainda mais explicitamente, a questão da volubilidade de Ernesto, a sua falta de reação e, de certo modo, de caráter. O conteúdo é praticamente o mesmo, mas a forma de apresentá-lo é bem mais requintada.

No capítulo V, quando Ernesto vai atrás do rival para explicar-lhe tudo, o rapaz de nariz comprido reflete e hesita antes de tomar a decisão de conversar com Ernesto e esclarecer a situação, o que mostra um pouco mais de aprofundamento psicológico no âmbito do pensamento da personagem. Além disso, uma extensa modificação ocorre de uma versão para outra:

Podia ser que ele falasse a verdade; era melhor saber tudo. Uma exposição franca salvava-os. Pensou nisto algum tempo, e disse, dando o braço a Ernesto:

- Vamos ao Passeio Público.

Em caminho referiram os nossos dous rivais tudo o que havia entre cada um deles e a moça; a descrição das contrações nervosas que a cara de ambos fazia a cada
Falaria ele verdade? Essa moça, que tanto amor lhe jurava, com quem meditava casar dentro de pouco tempo, mas de quem alguma vez desconfiara, teria dado efetivamente àquele homem o direito de a chamar sua? [...]

Seguiram caminho, a princípio silenciosos, não só porque a situação os acanhava naturalmente, mas também porque cada um deles receava ouvir uma cruel revelação. A conversa começou por 
revelação nova era digna e própria de um Homero. Ernesto tinha as faces afogueadas; o rapaz de nariz comprido estava pálido.

- Em suma, disse este descendo com o rival pela rua das Marrecas; fomos vilmente enganados.

- Fomos.

- Ambos temos-lhe amor...

- Creio que sim; pela minha parte não amei nunca assim... Que faremos?

Desprezá-la

- Não basta, disse Ernesto com resolução; é necessário uma vingança exemplar. Não estou disposto a ser ludibriado por esse modo...

- Mas repare, disse o rapaz de nariz comprido, que vingança poderemos nós tomar dela? Nenhuma. A verdadeira vingança é o desprezo... Ah! Rosina!

[...] cada um deles tinha casualmente uma carta da namorada no bolso. Foram ambas lidas, e averiguada mais uma vez a perfídia da moça, que respondia aos dois com expressões de ternura e apaixonado amor.

Depois de uma hora de confissões mútuas e projetos de vingança, concordaram os dois rivais amigos que a melhor desforra que podiam tomar dela, era mandar-lhe cada um deles uma carta de igual teor, declarando-lhe que se recusavam ao casamento e se despediam dela. monossílabos e frases truncadas, mas foi a pouco e pouco fazendo-se natural e correta. Tudo quanto os leitores sabem de um e outro foi ali exposto por ambos, e por ambos ouvido entre abatimento e cólera.

- Se tudo quanto o senhor diz é a expressão da verdade, observou o rapaz de nariz comprido descendo a rua das Marrecas, a conclusão é que fomos enganados..

- Vilmente enganados, emendou Ernesto. [...]

- Devo eu condenar tão ligeiramente aquela moça? perguntou ele a si mesmo; e não será este sujeito um pretendente vencido que, por semelhante meio quer obter a minha neutralidade?

$\mathrm{O}$ rosto de Ernesto não parecia dar razão à conjetura do rival; todavia, como o lance era grave e cumpria não ir por aparências, o rapaz de nariz comprido abriu de novo o capítulo das revelações, no que foi acompanhado pelo rival. Todas elas iam concordando entre si; [...]

O que porém decidiu tudo foi a apresentação de uma carta que cada um deles tinha casualmente no bolso. [...]

- Desprezemo-la, disse este, quando acabou de ler a carta do rival. [...]

- Mandemos-lhe uma carta de rompimento, mas uma carta de igual teor.

Quando a revelação da traição é feita, na segunda versão, o moço de nariz comprido não é tão precipitado em acreditar em Ernesto e julgar a moça. Várias provas são necessárias (como a carta, a descrição dos gestos etc.) para ele finalmente crer que havia sido enganado. Na primeira versão, a relação de ambos se torna mais amistosa, já que o próprio guarda-livros dá o braço a Ernesto para irem ao Passeio Público. O desfecho da situação é muito mais rápido e imediato, não há muitas reflexões nem dúvidas, como acontece na versão em livro, em que o rapaz de nariz comprido demora mais a acreditar em Ernesto.

Outra mudança relevante ocorre no último capítulo, quando Ernesto volta à casa de Rosina e ela lhe pede perdão, confessando ter escrito a carta ao rival (mas por 
culpa de Ernesto). Na primeira versão, Ernesto logo acredita na moça e considera-se culpado. Na versão em livro, Ernesto ainda desconfia um pouco de Rosina e a faz sofrer antes de aceitá-la novamente. O narrador também delineia o raciocínio de Ernesto ao explicar o porquê de ele acreditar na moça e perdoá-la, descrevendo assim uma espécie de lógica da mente fraca e, para utilizar as palavras de Rosina, "palerma" do moço:

\begin{tabular}{|c|c|}
\hline$J F$ & $H M N$ \\
\hline $\begin{array}{l}\text { - Oh! basta! basta! disse Ernesto } \\
\text { compreendendo tudo e caindo em si. } \\
\text { Vejo tudo claro; a culpa foi minha; eu } \\
\text { só fui culpado; perdoo-te a } \\
\text { leviandade; não! não! tu és que me } \\
\text { deves perdoar... } \\
\text { E foi por este teor fazendo um } \\
\text { longo discurso de contrição, } \\
\text { interrompido infelizmente pela tia de } \\
\text { Rosina. } \\
\text { As pazes estavam feitas. }\end{array}$ & $\begin{array}{l}\text { A alma de Ernesto ficou fortemente abalada com } \\
\text { esta exposição que a moça lhe fazia dos } \\
\text { acontecimentos. Era claro para ele que Rosina negaria } \\
\text { tudo, se o seu procedimento tivesse alguma intenção } \\
\text { má; a carta, diria que era imitação da sua letra. Mas } \\
\text { não; ela confessava tudo com a mais nobre e rude } \\
\text { singeleza deste mundo[...] } \\
\text { Decorreram alguns segundos de silêncio, em que a } \\
\text { moça tinha os olhos pregados no chão, na mais triste e } \\
\text { melancólica atitude que jamais teve uma donzela } \\
\text { arrependida. [...] } \\
\text { A moça ouviu ainda muitas cousas que lhe disse } \\
\text { Ernesto, e a todas respondeu com um ar tão contrito e } \\
\text { palavras tão repassadas de amargura, que o nosso } \\
\text { namorado sentia quase rebentarem-lhe as lágrimas dos } \\
\text { olhos. [...] } \\
\text { - Demais, disse Ernesto, o culpado de tudo fui eu, } \\
\text { francamente o confesso. Ambos nós temos que perdoar } \\
\text { um a outro; perdoo-lhe a leviandade; perdoa-me o fatal } \\
\text { arrufo? [...] }\end{array}$ \\
\hline
\end{tabular}

Outro ponto interessante a ser notado é que na primeira versão aparecia, uma única vez, o nome do rapaz de nariz comprido (Luiz Pereira), o qual é suprimido na segunda versão, e durante todo o conto o moço não tem nome, só sendo possível identificá-lo pelo adjetivo relativo à sua aparência (nariz comprido) ou pela função que ele exerce (guarda-livros, rival). É significativo pensarmos no adjetivo com que o narrador nomeia o rival de Ernesto. Nariz comprido remete a enxerido, intrometido, pessoa que se mete onde não foi chamada, justamente as qualidades pelas quais o guarda-livros é tomado por Ernesto.

Sendo assim, o que se pode notar ao analisar as diferenças de uma versão para outra é que, em geral, as mudanças parecem caminhar em três direções, pelo menos: uma diz respeito à ironia e às críticas que passam a ser um pouco mais sutis e menos 
explícitas; outra tem a ver com a supressão de alguns elementos que deem certezas e respostas prontas ao leitor; e uma terceira parece apontar para a tentativa (muitas vezes bem-sucedida) de afastamento dos padrões românticos e melodramáticos.

A conversa com o leitor e o modo como o narrador se dirige a ele podem ser encontrados em contos e livros posteriores e também na coletânea de 1873. No conto "Ernesto de tal", encontramos alguns deles, tais como: leitor ingênuo, leitor curioso, compassiva leitora. Machado já procura o leitor para ser seu cúmplice, para chamar-lhe a atenção ou para enganá-lo e busca contar com a complacência e conivência desse leitor.

Com a reescrita do conto, Machado questiona ainda mais as práticas tradicionais da época, ao privilegiar o distanciamento crítico, a reflexão e a análise, ainda que com ressalvas, evidentemente. Ele convoca o leitor a tomar parte da narrativa, exige uma postura mais ativa e participativa na construção do sentido do texto. Machado parece querer moldar e solicitar, desde aquela época, o leitor "ruminante", reflexivo, que estará efetivamente configurado em seus textos posteriores.

Por fim, acreditamos que este artigo pode contribuir para a desmistificação sobre as primeiras obras de Machado, consideradas por muitos textos de menor valor. Pensamos que muitos desses contos serviram de esboço e experimentação para temas e personagens que seriam reutilizados em textos posteriores da maturidade. Não seria "Ernesto de tal", por exemplo, um rascunho do retrato brasileiro que se configuraria mais tarde em Memórias póstumas de Brás Cubas? O país que oscilava entre capitalismo e escravidão e queria, não casar, mas lucrar da melhor forma possível, buscando uma supremacia qualquer que fosse.

Rosina em muito se assemelha também a Capitu, personagem primordial de Dom Casmurro. Os olhos da pretendente de Ernesto "não enganam ninguém... exceto os namorados. Os olhos dela são espertinhos e caçadores [...]". Ela, assim como Capitu, também não pertence a uma família rica, mas nem por isso deixa de ser vaidosa e "ainda assim está garrida e elegante". Rosina, semelhantemente à personagem de Dom Casmurro, quer, a qualquer custo, elevar o seu status social, quer casar bem, é ambiciosa e esperta, "não era inteiramente avessa aos impulsos do coração e à filosofia do amor; mas tinha ambição de figurar alguma cousa, morria por vestidos novos e 
espetáculos frequentes, gostava enfim de viver à luz pública." A dissimulação igualmente parece ser instrumento valioso para ambas as personagens.

As mudanças de uma versão para outra são fontes formidáveis, que indicam a preocupação do autor em reescrever seus textos e reformulá-los, levando em conta o gênero e o próprio meio de publicação. O cotejo das diferentes versões mostra ainda que a escrita não é um processo estanque e acabado, revelando a leitura crítica que o próprio autor fez de sua obra.

Referências:

ASSIS, Machado de. Ernesto de tal. Jornal das famílias - publicação illustrada, recreativa, artistica etc. Rio de Janeiro: Garnier, 1873. Tomo XI. p. 75-88 e p. 97-104.

. Histórias da meia-noite. Rio de Janeiro: BL Garnier, Livreiro-Editor do Instituto Historico, 1873.

Disponível O velho Senado. Brasília: Senado Federal / Conselho Editorial, 2004. p. 45 <http://www.senado.gov.br/publicacoes/conselho/asp/pdfS.asp?COD_PUBLICACAO= 230>. Acesso em: 13 de agosto de 2012.

COLLECÇÃO DAS LEIS DO IMPERIO DO BRASIL. Tomo XIII. Parte II. Rio de Janeiro: Typographia Nacional, 1851. p. 07. Disponível em: $<$ http://www.camara.gov.br/Internet/InfDoc/conteudo/colecoes/Legislacao/Legimp37.pdf $>$. Acesso em: 13 de agosto de 2012.

FAORO, Raymundo. Machado de Assis: a pirâmide e o trapézio. 4.ed. rev. São Paulo: Globo, 2001.

FRANCO, Maria. Sylvia. de Carvalho. As ideias estão no lugar. In: Cadernos de debate 1 - História do Brasil. São Paulo: Brasiliense, 1976.

GLEDSON, John, Machado de Assis: ficção e história. Trad. Sônia Coutinho. 2.ed. rev. São Paulo: Paz e Terra, 2003.

1872: "A parasita azul" - Ficção, nacionalismo e paródia. In: Cadernos de literatura brasileira, n. 23/24. São Paulo: Instituto Moreira Salles, 2008.

PASTA JÚNIOR, José Antonio. Singularidade do duplo no Brasil. In: CHEMANA, Roland (Org.). A clínica do especular na obra de Machado de Assis. Paris: Association Lacanienne Internationale, 2005. 
SANTIAGO, Silviano. Retórica da verossimilhança. In: Uma literatura nos trópicos: ensaios sobre dependência cultural. 2.ed. Rio de Janeiro: Rocco, 2000. p. 27.

SCHWARZ, Roberto. Ao vencedor as batatas: forma literária e processo social nos inícios do romance brasileiro. 5.ed. São Paulo: Duas Cidades; Editora 34, 2000.

STEIN, Ingrid. Figuras femininas em Machado de Assis. Rio de Janeiro: Paz e Terra, 1984.

WILLEMART, Philippe. Universo da criação literária: crítica genética, crítica pósmoderna? São Paulo: Edusp, 1993.

Flávia Barretto Corrêa Catita é mestranda em Literatura Brasileira na FFLCH - USP e bolsista da FAPESP com o projeto "Por uma edição crítica e genética virtual do livro Histórias da meia-noite, de Machado de Assis". Faz parte do grupo de pesquisa "A recepção crítica da obra de Machado de Assis". Desenvolveu, durante a graduação, projeto de Iniciação Científica, com apoio do CNPq, intitulado "Do Jornal das Famílias às Histórias da Meia-Noite: reescrita e criação nos primeiros contos de Machado de Assis", pelo qual recebeu menção honrosa no $18^{\circ}$ Simpósio de Iniciação Científica da USP. E-mail: <flaviabc10@gmail.com>

Recebido: $15 / 08 / 2012$

Aprovado: 29/10/2012 